\title{
Safety Analysis of Sea Transportation in Indonesia Case study : Crossing Between Countries In Sumatera Island (Batam - Singapore)
}

\author{
Danny Faturachman, Yoseph Arya Dewanto, and Gatot Dwi Adiatmojo
}

\begin{abstract}
As a border in Sumatrea Island, Batam City as a bridge between Indonesia and Singapore. For maritime safety affected business activity sustainable development especially sea transportation. Batam included in the province of Riau Islands and located in locations strategic considering in the border area between countries, neighbors with one business center in the world is Singapore and supported by the international transportation network with traffic crowded. Related to the sea transportation, there are 3 aspects intertwined each other, the traffic and sea transport, ports, and ship safety and security. Hence all parties pertaining to events on a voyage must meet the requirements that has been set. Through step concrete, the fulfillment of on the regulation of safety and security shipping will achieve the level of safety and a high security.
\end{abstract}

Index Terms - Batam, ferry, safety analysis, Singapore.

\section{INTRODUCTION}

Indonesia as an archipelago countries consisting thousands of islands and possessed of marine territory wide-ranging so that needed sea transportation as a means of mobility and national economic development improvement. The development of transportation in Indonesia, especially sea transportation has been increased nowadays. This is the impact of economic activities and social experience culture and society. In addition, Indonesian sea waters besides as a link among cities and island, also among countries. As the border in Sumatera Island, Batam as a bridge between Indonesia and Singapore. Geographically, Riau Islands province situated between $0^{\circ} 40^{\prime}$ south latitude and $07^{\circ} 19^{\prime}$ northern latitudes and between $103^{\circ} 3^{\prime}$ to $110^{\circ} 00^{\prime}$ east longitude, with the boundaries of as follows; Northern: Vietnam and Cambodia, Southern: Bangka Belitung province and Jambi province, Western: Singapore, Malaysia and Riau province, Eastern: Malaysia and West Kalimantan province. The province of Riau Islands consisting of cluster larger and small islands and each other connected by waters. Several islands relatively large of them are named Bintan Island where located the capital of province is Tanjung Pinang. Batam Island that was the center of the development of industry and trade, Rempang and Galang Island which is a region extension of territory industry of

Manuscript received February 29, 2016.

Danny Faturachman is with the Darma Persada University, Department of Marine Engineering, Jl. Radin Inten 2, Pondok Kelapa, Jakarta 13450, Indonesia

Yoseph Arya Dewanto was the Darma Persada University, Department of Marine Engineering, Jl. Radin Inten 2, Pondok Kelapa, Jakarta 13450, Indonesia

Gatot Dwi Adiatmojo is with the Renewable Energy Department, Darma Persada University, Jl. Radin Inten 2, Pondok Kelapa, Jakarta 13450, Indonesia
Batam, Karimun Island, Kundur Island, Lingga Island, Island of Bunguran in Natuna, and cluster of Anambas Island. In addition, Riau Islands province having smaller islands are almost spread across the city, including of them smaller islands that situated in the region of the borders of Indonesia.

\section{LITERATURE REVIEW}

\section{A. Regulation Review}

In act no 17 years 2008 Indonesian government about cruise states that:

- Ship safety and security is a state of the fulfillment safety requirements and security in waters on transport, ports, and environment maritime;

- Seaworthy of the ship is the state of a ship fulfilling the requirements ship safety, pollution prevention waters of a ship, crews, load line, loading, welfare crew and health passengers, the legal status of a ship, safety management and prevention pollution of a ship, and security management a ship to sail in certain aquatic;

- Ship safety is a state of vessel compliant material, construction, ship engines and electricity, stability, general arrangement and equipment, a salvage supporter and radio, electronic of the ship, as evidenced by certificate post examination and testing.

To control of shipping safety internationally set with terms as follows:

a. International Convention for the Safety Of Live At Sea (SOLAS) 1974, as refined and international rules this is concerning terms as follows:

a) Construction (of structures, stability, machinery and electricity installation, fire protection, detector fire and firemen);

b) Radio communication, navigation safety;

c) A device helper, like a buoy, sloop, raft helper;

d) The application of the provisions to improve safety and security shipping belong the application of International Safety Management (ISM) code, and the International Ship and Port facility Security (ISPS) code.

b. International Convention on Standards of Training, Certification, and Watch keeping for Seafarers, year 1978 and the revision on year 1995 .

c. International Convention on Maritime Search and Rescue, 1979.

d. International Aeronautical and Maritime Search and Rescue Manual (IAMSAR). 


\section{B. Review Batam City}

Batam City is one of municipal who are in the province of Riau Islands located at $0^{\circ} 25^{\prime} 9^{\prime \prime}-1^{\circ} 15^{\prime} 00^{\prime \prime}$ northern latitudes and $103^{\circ} 34^{\prime} 35^{\prime \prime}-104^{\circ} 26^{\prime} 4^{\prime \prime}$ east longitude. Batam City having broad territorial waters reached $1.570 \mathrm{~km}^{2}$. The land area inhabited by 988.55 peoples, so that population density in the city as many as 38.661 persons $/ \mathrm{km}^{2}$. This population is the third populous of Sumatra Island after Medan City and Padang City. Batam City consisting of so many regions, there are Batu Ampar, Belakang Padang, Bulang, Galang, Lubuk Baja, Sei Beduk, Batu Aji, Segulung, Bengkong, the city of Batam and Sekupang. Batam City is located very strategic island due to located along the international shipping with the limits of the area as follows: North Singapore and Malaysia, South Lingga district, West Karimun district, East the island of Bintan and Tanjung Pinang (source: Batam in figures 2010).

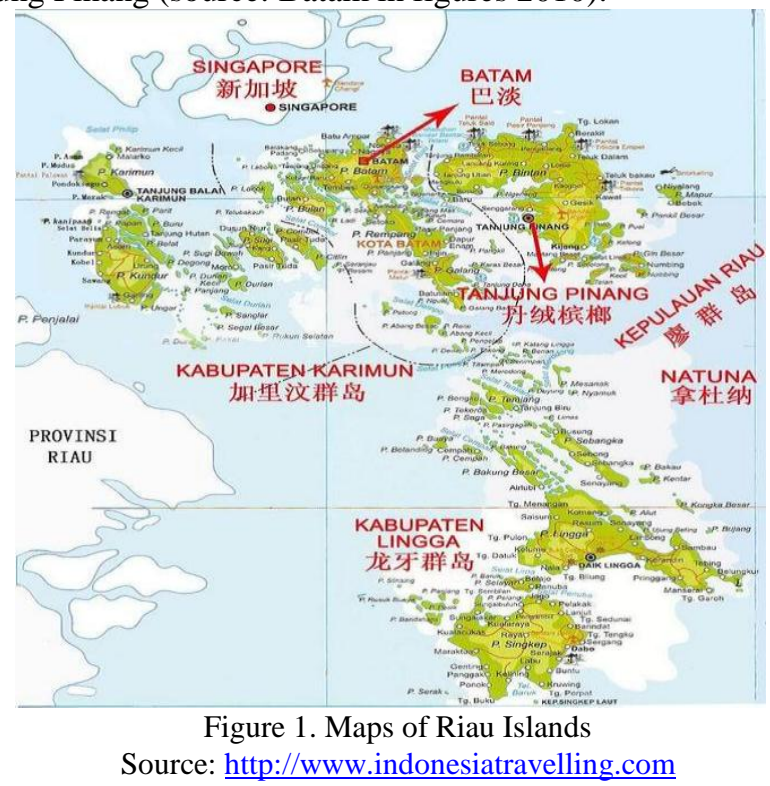

Batam City does not have natural resources which is abundant, hence economic activities the majority of the city depends on secondary sector and tertiary. This is reflected in the economic growth target the government of Batam that is driven by growth in the industrial sector and tourism. Batam who is regarded as the tropics, with an average temperature range from 24 up to 35 degrees centigrade ( 77 to 95 degrees Fahrenheit). Moisture in this area range from $73 \%$ to 96 percent. In general the rainy season starts from November until April and the dry season from May to October. Mean annual rainfall about $2600 \mathrm{~mm}$.

Transportation is a means of supporting mobility, where people can use the facilities in Batam public transport as taxi, buses, and motorcycles taxi. Besides transport, Batam that is also the islands regions, sea transport is one of the important transportation connected all the islands. The use of sea transportation connecting Batam with islands around and with neighboring countries as Singapore and Malaysia, make development and transport enough, as the ship ferry (ship crossing between countries).

\section{Overview of Ferry Terminal}

Ferry terminal consisting of two words namely ferry and terminal. Terminal is the point where passengers and goods in and out of the system and is essential component of transportation system (Morlok, 1991). While ferry is a ship transportation close range. So, ferry terminal can accommodate activity in and out passengers from transportation a ship close range or ferry boat. Terminal also as a forum for activity the process displacement passengers from sub transit system to the sub transit system from a different characteristic. In other words meaning of sea transport to transport land. Viewed from the scope of port system, passenger terminal is a ferry components port sub system that serves for passengers inter island by means of a ship.

\section{FERry BoAT ClassificAtion}

Ferry boat have some type and classified based on the way landing and also how loading and unloading a ship ferry:

a. Based on the way landing .Landing way consisting of two kinds of:

1. Ferry boat who land directly in the sand who named LCM (Landing Craft Manual) or LST (Landing Site Tanks). Access of the ship located at the upstream and the stern as well as having capacity conveyance greater.

2. Another ferry boat that landed in a dock. A ship this requires a wharf for berthing. Access charge there are in the hull, upstream, and stern but access in the hull not common for their place on when docked in a dock. Access passengers being on the side, directly into deck side.

b. Loading and unloading based on the way. As a broad outline technology loading and fit on the ferry can vary as follows:

1. Lo / Lo (Lift on / Lift off), namely vessel with the transfer of charge in vertical synchronization;

2. Ro / Ro (Roll on / Roll off), namely vessel with the transfer of charge horizontally;

3. Suction, namely types of vessels with the charge by means of suck / pump through a pipeline, usually combined with equipment conveyor belt (conveyor belt);

4. Special, namely types of vessels who handles one kind of charge. To another ferry boat, because of the charge of people and vehicles and did not need equipment loading and unloading special, type suitable is Ro / Ro.

Included in the Ro/ Ro vessel type:

1. A short distance vessel

2. Intermediate distance vessel

3. Long distance vessel

The type of ship that sailed between Batam - Singapore is a short distance vessel called also fast ferry. This ship could called fast ferry because his speed in splitting the beach and the strait .Usually ships this type worn in the areas of waters or the sea no undulating high. So very suitable for transportation coastal streams and lakes that the waves not to strong. This type of ships much worn by a passenger ship that connects small islands. As is the case with Batam - Singapore, Batam Malaysia, Batam - Tanjung Pinang, and Batam - Riau the mainland. 


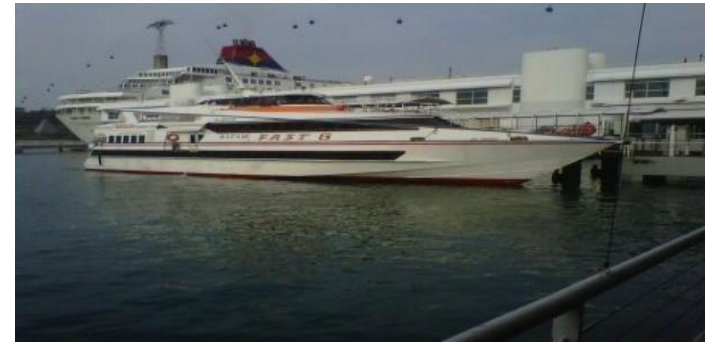

Fig. 2 Example of Fast Ferry

\section{RESUlt AND DisCUSSION}

1. Sekupang Ferry Terminal, Batam

Sekupang is a terminal ferry new renovated by the government. The port was also used for one of the tourism in Batam. The port serving defections international to Harbor Front terminal ferry in Singapore.

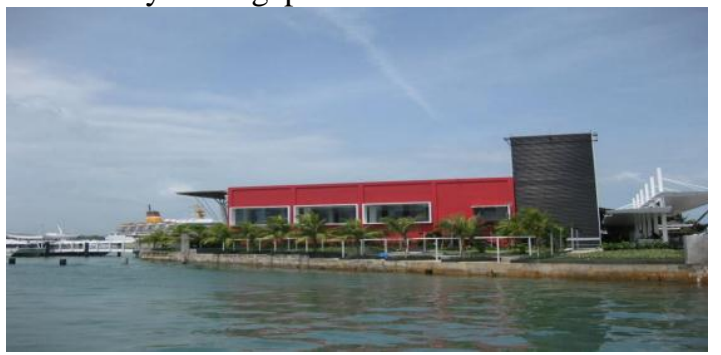

Fig. 3 Sekupang Ferry Terminal

The port consisting of 2 floor:

1. Discharging the steel structure in components column buffer, buffer glass \& the roof;

2. Separation circulation passengers of arrivals and departures in the first floor with the entrance different;

3. Create a continuous space;

4. Use structures space landscapes of wide.

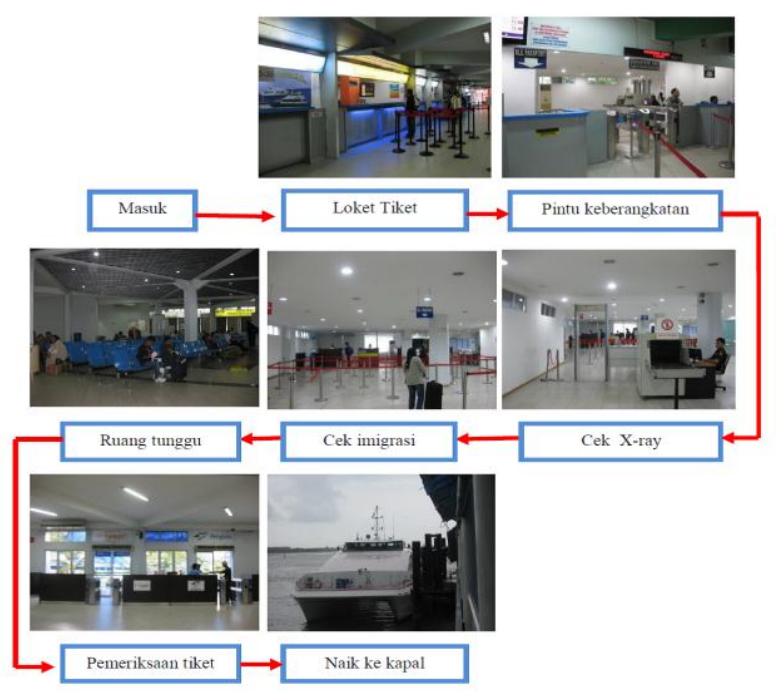

Fig.4 Circulation of Passengers Depart in Sekupang Terminal Ferry

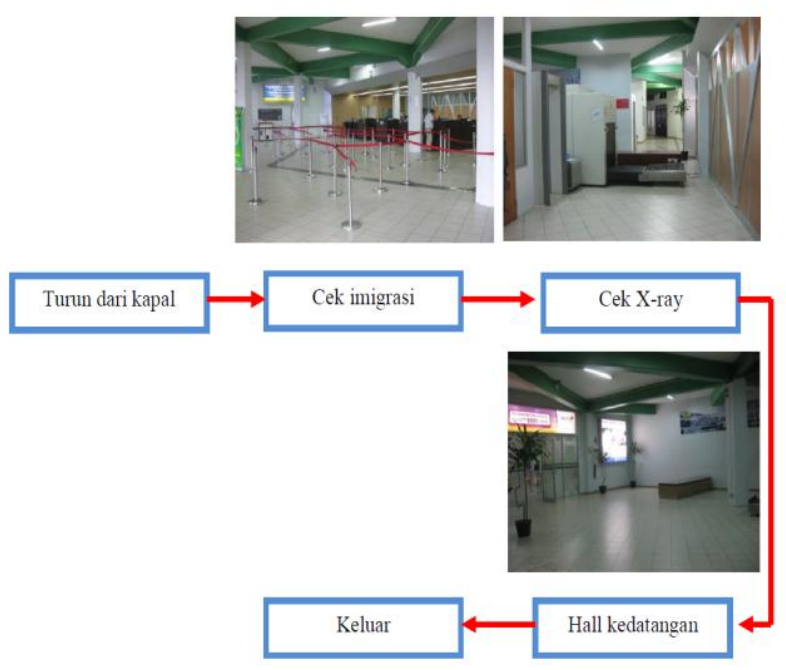

Fig. 5 Circulation of Passengers Arriving in Sekupang Terminal Ferry

2. Harbor Front Ferry Terminal, Singapore

The port is the busiest sea port in Singapore, because here most passengers from Batam, Tanjung Balai Karimun, Tanjung Pinang and cruises down, before entering Singapore. Located in front of the island of prosperity, where Sentosa Island is tourism island, where there are various tourist entertainments ranging from resorts, hotel, a golf course, aquarium underwater, the beach and more including Universal Studios. .On the harbor is port front of the busiest container in Singapore. Nearby there are also of the mosque relic Johor, that there are tombs royal descent Johor that one time when the Singapore by their kingdom. Harbor front itself is were mall that sell various trinkets, starting from the clothes, electronic, food lawful and others, so port harbor is the front fused and are in a mall.

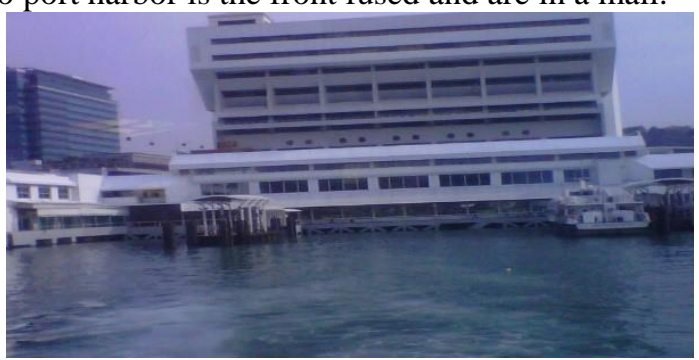

Fig. 6 Harbor Front Terminal Ferry, Singapore

Examples of safety tools in fast ferry:

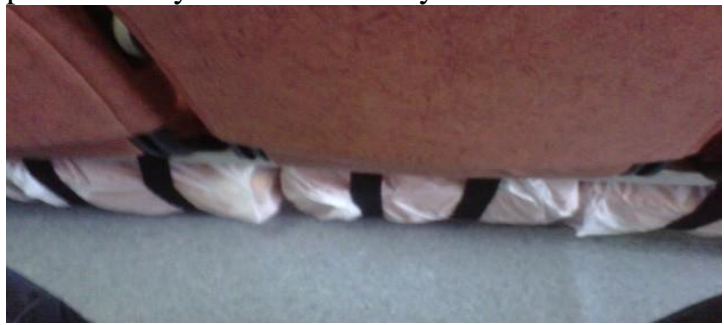

Fig. 7 Place of Laying Life Jacket in Fast Ferry 


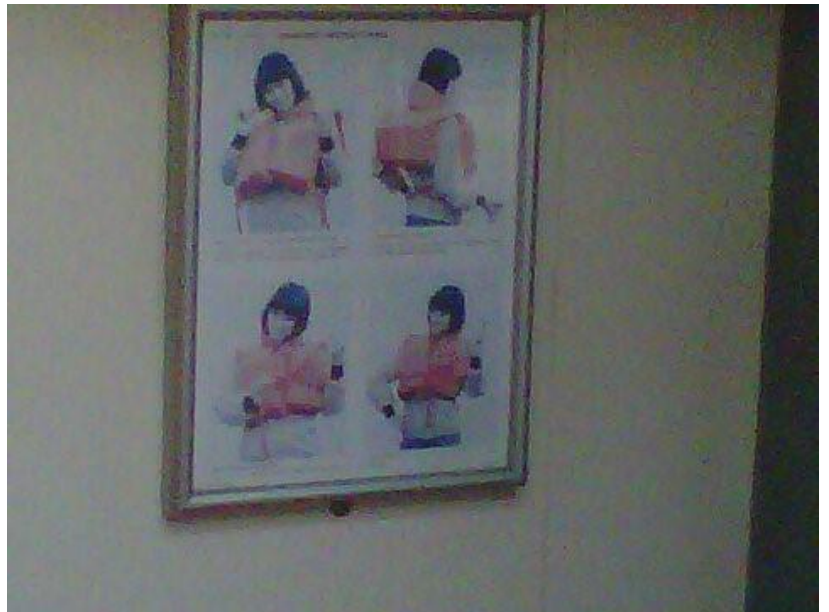

Fig. 8 Board aids discharging life jacket

Schedule departure ferry and the ticket price:

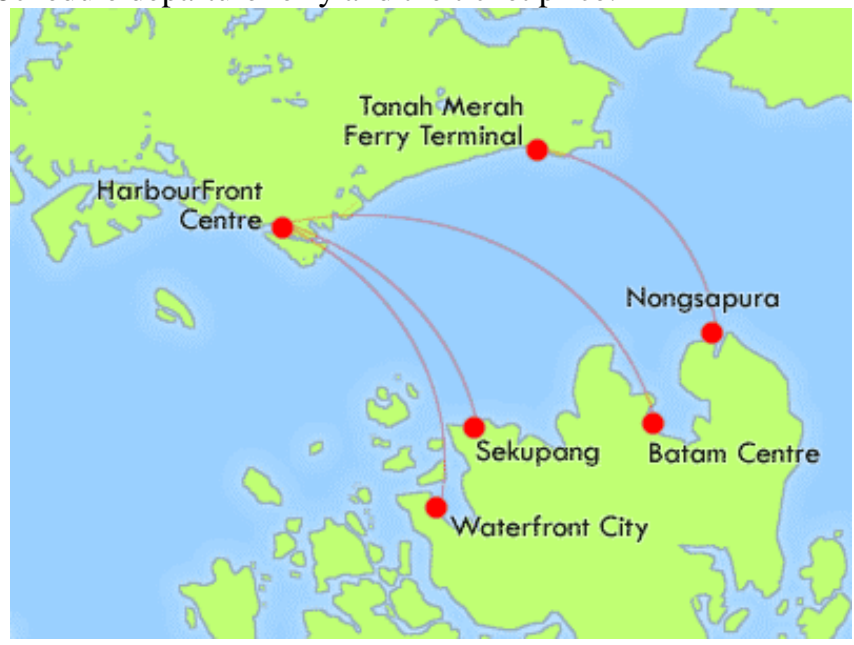

Fig. 9 Schedule Shipping Ferry of All Port Batam - Singapore

Schedule the departure of a vessel ferry Batam Fast from Sekupang to Harbor Front, Singapore. Ferry Batam Fast schedule can be seen in table 1 . And may change at any time without advance notice. Info thing can be accessed in www.batamfast.com

TABLE I

SCHEDULE OF FerRy BATAM FAST SEKUPANG - HARBoR FRONT

\begin{tabular}{||c|c|}
\hline $\begin{array}{c}\text { Harbourfront } \\
\text { to } \\
\text { Sekupang } \\
\text { Singapore Time }\end{array}$ & $\begin{array}{c}\text { Sekupang } \\
\text { to } \\
\text { Harbourfront } \\
\text { Batam Time }\end{array}$ \\
\hline \hline $07: 50$ & $06: 00$ \\
\hline $08: 20$ & $07: 10$ \\
\hline $09: 20$ & $08: 30$ \\
\hline $11: 10$ & $10: 30$ \\
\hline $15: 10$ & $15: 00$ \\
\hline $17: 30$ & $16: 10$ \\
\hline $19: 30$ & $17: 10$ \\
\hline $21: 45$ & $19: 00$ \\
\hline
\end{tabular}

TABLE II

Ticket FARE To / From: HaRbor Front to CEnTRE, SEKuPANG,

\begin{tabular}{|l|c|l|l|}
\hline Type & Ticket Fare & Surcharge & Total \\
\hline $\begin{array}{l}\text { ADULT -2 } \\
\text { Way }\end{array}$ & $\$ 22.00$ & $\begin{array}{l}\$ 14.00 \text { (pay in Sing) } \\
\text { and } \$ 12.00 \text { in Batam }\end{array}$ & $\$ 48.00$ \\
\hline $\begin{array}{l}\text { ADULT - } \\
\text { Way }\end{array}$ & $\$ 18.00$ & $\begin{array}{l}\$ 7.00 \text { (in Batam) and } \\
\$ 6.00 \text { in Sing }\end{array}$ & $\$ 31.00$ \\
\hline $\begin{array}{l}\text { CHILD / } \\
\text { INFANT }- \\
2 \text { Way }\end{array}$ & $\$ 19.00$ & $\begin{array}{l}\$ 14.00 \text { (pay in Sing) } \\
\text { and } \$ 12.00 \text { in Batam }\end{array}$ & $\$ 45.00$ \\
\hline $\begin{array}{l}\text { CHILD / } \\
\text { INFANT }- \\
1 \text { Way }\end{array}$ & $\$ 15.00$ & $\begin{array}{l}\$ 7.00 \text { in Batam and } \\
\$ 6.00 \text { in Sing }\end{array}$ & $\$ 28.00$ \\
\hline
\end{tabular}

All published fares exclude Departure Fee / Terminal Fee. Batam Terminal Fee will be payable by passengers prior to departure.

Only 2-way Tickets available for Harbor Front Centre (HFC) $<->$ Waterfront City (WFC).

\section{CONCLUSION}

1. Batam City in general and Sekupang Terminal ferry in particular has facilities and facilities physical international standard, technology mastery and a greater close to Singapore as the power possessed so can be optimized its use in increase the total of passenger that can be served so that it will increase regional income.

2. Safety facilities in a ship basically enough available where his safety (life jacket) there is enough and put under the passenger seat so that it can be immediate use if the case of the accident.

3. For fast ferry shipping route Batam - Singapore returns especially in Sekupang has ordered well and operating in accordance with the schedule. Many choice port in Batam (5 port crossing) not causing overcrowding and the timetable mess and collect in the berthing (berth both in Batam and Singapore). This is because all ships complied with the schedule and crossing to Singapore will relative not long only about 45 minutes for one trips.

4. Sekupang having port facilities that are worth as international ferry terminal where it has been differentiated between the departure and arrival of passengers and also has been security have a procedure is a good enough on the floor where floor of 1 is common zone, the arrival of passengers and management zone with the entrance different. On the floor of 2 is departure passenger zone.

5. Harbor Front in Singapore are modern terminal ferry have fused with malls and is the gate enter Sentosa Island which is a region famous tourist and busiest in Singapore

\section{ACKNOWLEDGMENT}

Special thanks for the Research institutes, community empowerment and partnership Darma Persada University for the funding in this research and also financing the attending of 
this conference in Pattaya, Thailand.

\section{REFERENCES}

[1] Batam Industrial Development Authority, 2010. Development Progress of Batam, First Semester of 2010, Batam.

[2] ICT Expo Langkah Menuju Batam Digital Island, Tribun Batam - Senin, 18 Oktober 2010, http://batam.tribunnews.com.

[3] Peraturan Pemerintah No. 61 tahun 2009 tentang Kepelabuhan.

[4] Rusda Irawati, SE., 2011. Analisis SWOT Pelabuhan Ferry Internasional Sekupang.

[5] Surat Perjanjian kerjasama Nomor 12/PERJ-KA/VIII/2004 dan 111/IDC-OB/SP/BOTSKP/VIII/2004: Untuk Membangun, Mengelola dan Memelihara Terminal Ferry Internasional Sekupang

[6] UU RI Nomor 44 Tahun 2007

[7] YJ Naim, 2011. Batam Layak Dapat Insentif Pertumbuhan Ekonomi Tinggi, Antara News Kepulauan Riau, 6 Januari 2011, diambil dari http://kepri.antaranews.com.

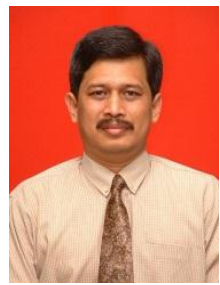

First A. Author born in Jakarta, 17 ${ }^{\text {th }}$ August 1967. Bachelor degree from Darma Persada University, majoring in Shipbuilding Engineering. The Master degree from Univerity Malaysia Pahang, majoring Technology Management. The author's major field of study is shipbuilding technology and ship accident..

He has been a lecturer since 1993. Already have many position in university like the head of laboratory, deputy dean and the last position is the HEAD OF MARINE

ENGINEERING DEPARTMENT, FACULTY OF OCEAN TECHNOLOGY,

DARMA PERSADA UNIVERSITY. Some of journal published:

1. Danny Faturachman, Shariman Mustafa, Agung Sudrajad. 2012. A Rescuee Boat Design Utilizing Reused Plastic Bottles for Accident Preventation, Mechanical Engineering Research Journal, Vol. 2, No. 1 June, 2012, 88-94.

2. Danny Faturachman, Shariman Mustafa, 2012. Sea Transportation Accident Analysis in Indonesia, Procedia Vol. 40 (2012) 616-621.

Danny Faturachman, Shariman Mustafa, 2012. Performance of Safety Sea Transportation, Procedia Vol. 57 (2012) 368-372 